\title{
Climatic tolerances and zoogeography of the late Pleistocene beetle fauna of Beringia
}

\section{La tolérance au climat et la zoogéographie de la faune des coléoptères de la Béringie, à la fin du Pléistocène Klima-Toleranzen und Zoogeographie der Käfer-Fauna der Bering-Insel im späten Pleistozän}

\author{
Scott A. Elias
}

Volume 54, numéro 2, 2000

URI : https://id.erudit.org/iderudit/004813ar

DOI : https://doi.org/10.7202/004813ar

Aller au sommaire du numéro

Éditeur(s)

Les Presses de l'Université de Montréal

ISSN

0705-7199 (imprimé)

1492-143X (numérique)

Découvrir la revue

Citer cet article

Elias, S. A. (2000). Climatic tolerances and zoogeography of the late Pleistocene beetle fauna of Beringia. Géographie physique et Quaternaire, 54(2), 143-155. https://doi.org/10.7202/004813ar

\section{Résumé de l'article}

L'étude des coléoptères fossiles joue un rôle important dans la reconstitution des paléoenvironnements de la Béringie. À ce jour, plus de 25 sites fossilifères ont été étudiés pour leurs assemblages d'insectes. Plus de 300 espèces de coléoptères ont été identifiées, dont 147 espèces carnivores ou détritivores utiles aux reconstitutions paléoclimatiques. L'auteur a confectionné des enveloppes climatiques (les paramètres climatiques qui décrivent les sites où l'on trouve présentement les espèces de coléoptères) pour réaliser des études paléoclimatiques (aires climatiques mutuelles). Cet article décrit les exigences climatiques de plusieurs espèces de coléoptères et leur histoire zoogéographique depuis la période ayant précédé le dernier interglaciaire. Les assemblages fossiles incluent 14 espèces arctiquesalpines, 66 espèces boréales-arctiques et 68 espèces tempérées-boréales. Le plus grand pourcentage d'espèces ayant des exigences thermiques réduites se trouve dans le groupe des espèces arctiques-alpines. La majorité des autres espèces ont de grandes exigences thermiques. En comparant la répartition moderne des espèces à celles, plus anciennes, reconstituées grâce aux fossiles nord-américains, il semble que quelques espèces soient demeurées exclusivement en Béringie pendant la fin du Pléistocène. Ces espèces béringiennes représentent $64 \%$ de toutes les espèces arctiques-alpines des assemblages fossiles, $34 \%$ des espèces boréales-arctiques et seulement $1 \%$ des espèces tempérées-boréales.
Tous droits réservés @ Les Presses de l'Université de Montréal,2000

Ce document est protégé par la loi sur le droit d'auteur. L'utilisation des services d'Érudit (y compris la reproduction) est assujettie à sa politique d'utilisation que vous pouvez consulter en ligne.

https://apropos.erudit.org/fr/usagers/politique-dutilisation/ 


\title{
CLIMATIC TOLERANCES AND ZOOGEOGRAPHY OF THE LATE PLEISTOCENE BEETLE FAUNA OF BERINGIA
}

\author{
Scott A. ELIAS ${ }^{*}$, University of Colorado, Institute of Arctic and Alpine Research, Boulder, Colorado, 80309-045, C. B. 450, U.S.A.
}

ABSTRACT The study of fossil beetles has played an important role in the reconstruction of Beringian paleoenvironments. More than 25 fossil localities have yielded Late Pleistocene beetle assemblages, comprising more than 300 species, of which about 147 are predators and scavengers, groups which are suitable for paleoclimatic reconstruction. The author has developed climate envelopes (climatic parameters characterizing the modern localities in which species are found) for these species, in order to perform mutual climatic range paleotemperature studies. This paper describes the thermal requirements of these beetles, and their zoogeographic history since the interval just prior to the last interglacial period. The fossil assemblages include 14 arctic and alpine species, 66 boreo-arctic species, and 68 boreal and temperate species. The greatest percentage of species with restricted thermal requirements occurs in the arctic and alpine group. The majority of boreo-arctic and boreal and temperate species have very broad thermal requirements. Based on modern distribution and the North American fossil record, it appears that some species resided exclusively in Beringia during the Late Pleistocene. These Beringian species comprise $64 \%$ of the arctic and alpine species found in the fossil assemblages, $34 \%$ of the boreo-arctic species, and only $1 \%$ of the boreal and temperate species.
RÉSUMÉ La tolérance au climat et la zoogéographie de la faune des coléoptères de la Béringie, à la fin du Pléistocène. L'étude des coléoptères fossiles joue un rôle important dans la reconstitution des paléoenvironnements de la Béringie. À ce jour, plus de 25 sites fossilifères ont été étudiés pour leurs assemblages d'insectes. Plus de 300 espèces de coléoptères ont été identifiées, dont 147 espèces carnivores ou détritivores utiles aux reconstitutions paléoclimatiques. L'auteur a confectionné des enveloppes climatiques (les paramètres climatiques qui décrivent les sites où l'on trouve présentement les espèces de coléoptères) pour réaliser des études paléoclimatiques (aires climatiques mutuelles). Cet article décrit les exigences climatiques de plusieurs espèces de coléoptères et leur histoire zoogéographique depuis la période ayant précédé le dernier interglaciaire. Les assemblages fossiles incluent 14 espèces arctiquesalpines, 66 espèces boréales-arctiques et 68 espèces tempérées-boréales. Le plus grand pourcentage d'espèces ayant des exigences thermiques réduites se trouve dans le groupe des espèces arctiques-alpines. La majorité des autres espèces ont de grandes exigences thermiques. En comparant la répartition moderne des espèces à celles, plus anciennes, reconstituées grâce aux fossiles nord-américains, il semble que quelques espèces soient demeurées exclusivement en Béringie pendant la fin du Pléistocène. Ces espèces béringiennes représentent $64 \%$ de toutes les espèces arctiques-alpines des assemblages fossiles, $34 \%$ des espèces boréales-arctiques et seulement $1 \%$ des espèces tempérées-boréales.
ZUSAMMENFASSUNG Klima-Toleranzen und Zoogeographie der Käfer-Fauna der Bering-Insel im späten Pleistozän. Das Studium von Käfer-Fossilen hat bei der Rekonstruktion der Paläoumwelt der Bering-Insel eine wichtige Rolle gespielt. Über 25 Fossilfundstätten ergaben Käfer-Einheiten aus dem späten Pleistozän. Sie umfassten über 300 Arten, von denen etwa 147 den Fleischund Aasfressern angehören, den für die paläoklimatische Rekonstruktion brauchbaren Gruppen. Der Autor hat klimatische Hüllen (klimatische Parameter, welche die modernen Plätze charakterisieren, in denen die Arten zu finden sind) für diese Arten entwickelt, um paläoklimatische Studien durchzuführen (wechselseitige klimatische Reichweite). Dieser Artikel beschreibt die klimatischen Ansprüche dieser Käfer und ihre zoogeographische Geschichte seit dem direkt vor dem letzten Interglazial gelegenen Intervall. Die fossilen Einheiten umschließen 14 arktische und alpine Arten, 66 boreal-arktische Arten und 68 boreal-gemäßigte Arten. Der größte Anteil von Arten mit begrenzten klimatischen Ansprüchen ist in der arktischen und alpinen Gruppe zu finden. Die Mehrzahl der boreal-arktischen und boreal-gemäßigten Arten haben hohe klimatische Ansprüche. Stützt man sich auf die moderne Verteilung und den nordamerikanischen Fossil-Beleg, wird deutlich, dass einige Arten im späten Pleistozän ausschließlich in der Bering-Insel vorhanden waren. Diese Bering-Arten umfassen $64 \%$ der in den FossilEinheiten gefundenen arktischen und alpinen Arten, $34 \%$ der boreal-arktischen Arten und nur $1 \%$ der boreal-gemäßigten Arten.

\footnotetext{
Manuscrit reçu le 26 juillet 1999 ; manuscrit révisé accepté le 29 mars 2000

* Present address: Geography Department, Royal Holloway - University of London, Egham, Surrey TW20 0EX, United Kingdom

E-mail address: s.elias@rhul.ac.uk
} 


\section{INTRODUCTION}

The reconstruction of paleoenvironments is an essential element in the development of our understanding of the ancient region, Beringia. This was the only large, unglaciated landmass that existed in the northern high latitudes during Late Pleistocene glaciations. The ice-free regions of northeastern Siberia, Alaska, the Yukon Territory, and the exposed continental shelf regions of the Bering and Chukchi seas served as a biological refuge for cold-adapted flora and fauna. Because of excellent fossil preservation in permanently frozen soils, Beringia has yielded an exceptionally detailed record of Pleistocene flora and fauna (e.g., Guthrie, 1990). During the last 35 years, paleontologists including John Matthews, Richard Morlan, Robert Nelson, and myself have analyzed more than 25 sites containing fossil insect assemblages dating to the Late Pleistocene. These sites have yielded about 300 species of insects, mainly beetles (Coleoptera). These fossils have provided a wealth of proxy data that help us reconstruct Beringian environments. One of the chief kinds of paleoenvironmental data extracted from the fossil beetle assemblages is paleotemperature. Beetles, especially predators and scavengers, have been shown to be sensitive, reliable temperature indicators (Coope, 1977; Elias, 1994).

During the past few years, I have developed paleoclimatic reconstructions for Central Beringia (the Bering Land Bridge) and Eastern Beringia (Alaska and the Yukon Territory) (Elias et al., 1996b; Elias et al., 1997; Elias, 1999; Elias et al.,1999a). This work has entailed the construction of "climate envelopes" for the predatory and scavenging beetle species found in the Beringian assemblages. The modern distributions of species found in fossil assemblages fall within certain climatic parameters. When these parameters are plotted for the modern collecting localities of a species, its geographic distribution translates into a climate envelope (Atkinson et al., 1986). These climate envelopes vary from broad to narrow, depending on the range of thermal tolerances of the species. The two parameters developed thus far are the mean temperature of the warmest month of the year (TMAX), and the mean temperature of the coldest month of the year (TMIN). The primary use of these climate envelopes is to develop mutual climatic range (MCR) estimates of these parameters, based on the overlap of climate envelopes of species in fossil assemblages. However, the climate envelopes themselves reveal considerable information about the thermal requirements of the species concerned. In this paper, I discuss the climatic tolerances of species of predatory and scavenging beetles found in Beringian fossil assemblages. Surprisingly, the majority of species found in late Pleistocene Beringian fossil assemblages are not purely arctic tundra beetles. Many are adapted to both arctic and boreal climates, and others are adapted to boreal and temperate climates. An analysis of the thermal requirements of these various groups constitutes the first part of this paper.

Because Beringia was a refuge for cold-adapted beetles, the Pleistocene fossil record of that region is particularly interesting. Some of the beetle species found today in Alaska and the Yukon Territory are thought by taxonomists to have evolved in situ in Beringia during late Tertiary to early Quaternary times (Ball, 1966). The fossil record sheds new light on this topic, documenting the species that lived in the various parts of Beringia during the glacial and interglacial periods. That is the second topic of this paper.

\section{METHODS}

The climate envelopes discussed here were developed by Kathy Anderson and me. We used a $25-\mathrm{km}$ gridded North American climate database (Bartlein et al., 1994) to pair climate parameters with the modern beetle collection sites, using the geographically nearest grid location to each collecting site. We then plotted the climatic parameters of each of these localities on diagrams of TMAX against the difference between the mean July and mean January temperature (TRANGE). We plotted climate envelopes for species of predators and scavengers found in Beringian fossil assemblages ranging in age from about 140000 to $10000 \mathrm{yr}$ BP. The species belong to the families Carabidae (ground beetles), Dytiscidae (predaceous diving beetles), Hydrophilidae (water scavenger beetles), Staphylinidae (rove beetles), Scarabaeidae (dung beetles), and Silphidae (carrion beetles). The beetles in these families probably respond to climatic change by shifting their ranges more readily than do most plant-feeding beetles. The ranges of plant feeding insects are necessarily restricted to the ranges of their host plants, which may or may not respond rapidly to changing climates (Elias, 1994).

The species' climatic tolerance data are shown in Table I. I calculated the TMAX and TMIN ranges for each species, and listed the species in zoogeographic groups (each group is listed in taxonomic order). These groups are based on the modern distributions of the species. Arctic and alpine species are those that are found today only in tundra regions, either at high elevation, high latitude, or both. Boreo-arctic species are those with modern ranges that include both the arctic, alpine, and boreal (coniferous forest) zones of North America, including montane forests in mountain chains south of Canada. Boreal and temperate species are those with modern ranges either in the boreal zone, the temperate zone, or both.

To classify the thermal tolerances of the beetle species, I grouped them according to the range of their TMAX values. I considered as stenothermic the species with TMAX ranges less than or equal to $5^{\circ} \mathrm{C}$. These beetles have limited thermal tolerances. I considered as mesothermic the species with TMAX ranges between 5 and $10^{\circ} \mathrm{C}$. These beetles have only moderately restricted thermal tolerances. I considered as eurythermic the species with TMAX ranges greater than $10^{\circ} \mathrm{C}$. These beetles are adapted to a wide range of summer temperatures.

In an attempt to classify the long-term zoogeographic patterns of beetle species found in late Pleistocene Beringian assemblages, I searched the literature concerning late Pleistocene beetle assemblages from North American regions south of the Laurentide and Cordilleran ice sheets. These fossil assemblages have recently been analyzed for 
TABLE I

Mutual Climatic Range estimates for beetle species found in late Pleistocene fossil assemblages from Alaska and the Yukon Territory

\begin{tabular}{|c|c|c|c|c|}
\hline Species & $\operatorname{TMAX}\left({ }^{\circ} \mathrm{C}\right)$ & TMAX range & $\operatorname{TMIN}\left({ }^{\circ} \mathrm{C}\right)$ & TMIN range \\
\hline \multicolumn{5}{|l|}{ Arctic \& Alpine Species } \\
\hline \multicolumn{5}{|l|}{ Carabidae } \\
\hline Blethisa catenaria Brown & $7-13.5$ & 6.5 & -38.5 to -21 & 17.5 \\
\hline Bembidion dauricum (Mots.) & $7.5-13.5$ & 6 & -37.5 to -17 & 20.5 \\
\hline Bembidion umiatense Lth. * & $7.5-10$ & 2.5 & -33 to -28 & 5 \\
\hline Pterostichus agonus Horn* & $5-13$ & 6 & -39 to -15 & 24 \\
\hline Pterostichus auriga Ball ${ }^{*}$ & $2.5-14.5$ & 12 & -31.5 to -16.5 & 15 \\
\hline Pterostichus costatus (Mén.)* & $5.25-10.25$ & 5 & -36.75 to -20.25 & 16.5 \\
\hline Pterostichus sublaevis (Sahlb.) & $6.5-14$ & 7.5 & -39 to -13.5 & 25.5 \\
\hline Poecilus nearcticus (Lth.) $)^{*}$ & 7-11 & 4 & -36 to -27 & 9 \\
\hline Amara alpina (Payk.) & $5-10.5$ & 5.5 & -39.5 to -5.5 & 34 \\
\hline Amara bokori Csiki* & $7-16$ & 9 & -38 to -12.5 & 25.5 \\
\hline \multicolumn{5}{|l|}{ Hydrophilidae } \\
\hline Helophorus splendidus Sahlb. & $8.25-10.25$ & 2 & -34.25 to -27.25 & 7 \\
\hline \multicolumn{5}{|l|}{ Staphylinidae } \\
\hline Holoboreaphilus nordenskioeldi Mäkl. & $5.5-14.5$ & 9 & -37.75 to -14.5 & 23.25 \\
\hline Micralymma brevilingue Schiodt.* & 3-12.5 & 9.5 & -38.5 to -18 & 20.5 \\
\hline Tachinus brevipennis Sahlb.* & $3.5-10.5$ & 7 & -36.5 to -17.5 & 19 \\
\hline Mean values & $5.7-12.4$ & 6.7 & -36.8 to -18.1 & 18.7 \\
\hline \multicolumn{5}{|l|}{ Boreo-Arctic and Boreo-alpine species } \\
\hline \multicolumn{5}{|l|}{ Carabidae } \\
\hline Carabus chamissonis Fisch. & $5.5-20$ & 14.5 & -39.5 to -7.5 & 32 \\
\hline Carabus taedatus Fabr. & $10.5-17$ & 6.5 & -36 to 0 & 36 \\
\hline Carabus truncaticollis Eschz. & $3.5-17.25$ & 13.75 & -42 to -9.25 & 32.75 \\
\hline Pelophila borealis (Payk.) & $7.5-16.5$ & 9 & -37 to -3.5 & 33.5 \\
\hline Nebria gebleri Dej. & $8.5-19.5$ & 11 & -30.5 to -6.75 & 23.75 \\
\hline Nebria metallica Fisch. & $9-17$ & 8 & -23 to 0 & 23 \\
\hline Nebria nivalis (Payk.) & $3-15.5$ & 12.5 & -42 to -10 & 32 \\
\hline Notiophilus borealis Harr. & $4.5-20$ & 15.5 & -40.5 to -2 & 38.5 \\
\hline Diacheila arctica (Fald.) & $11-12.5$ & 1.5 & -24.5 to -7.75 & 16.75 \\
\hline Diacheila polita (Fald.) & $2.5-16$ & 13.5 & -41.75 to 0 & 41.75 \\
\hline Elaphrus parviceps VD* & $8.75-16$ & 7.25 & -36.5 to -6 & 30.5 \\
\hline Elaphrus tuberculatus Mäkl.* & 9-16 & 7 & -36 to -14 & 22 \\
\hline Dyschirius melancholicus Putz.. & $7-16.5$ & 9.5 & -38 to -1 & 37 \\
\hline Asaphidion alaskanum Wickh. ${ }^{*}$ & $5-15$ & 10 & -39.75 to -13 & 26.75 \\
\hline Bembidion arcticum Lth. ${ }^{*}$ & $6-15$ & 9 & -38 to -9 & 29 \\
\hline Bembidion grapii Gyll. & $8.5-20.5$ & 12 & -37.5 to -2.5 & 35 \\
\hline Bembidion hastii Sahlb. & $6-16.75$ & 10.75 & -39.5 to -0.75 & 38.75 \\
\hline Bembidion sordidum (Kby.) & 7-19.5 & 12.5 & -37.5 to -2 & 35.5 \\
\hline Bembidion transparens (Gebl.) & $11-22$ & 11 & -34.5 to 0 & 34.5 \\
\hline Stereocerus haematopus (Dej.) & $5-18.5$ & 13.5 & -40.5 to -6.5 & 34 \\
\hline Pterostichus arcticola (Chd.) & $4-15$ & 11 & -42 to -15 & 27 \\
\hline Pterostichus barryorum Ball* & $8-17.5$ & 9.5 & -39.5 to -19.5 & 20 \\
\hline Pterostichus brevicornis (Kby.) & $4.5-15$ & 10.5 & -41.5 to -15 & 26.5 \\
\hline Pterostichus bryanti VD & $7-16$ & 9 & -31 to -14.5 & 16.5 \\
\hline Pterostichus caribou Ball & 5.5 to 14 & 8.5 & -39.5 to -18.25 & 21.25 \\
\hline Pterostichus circulosus Lth.* & 7.5-18 & 11.5 & -35 to -21.5 & 13.5 \\
\hline Pterostichus empetricola (Dej.) & $10.5-15.5$ & 5 & -34.5 to -4.5 & 30 \\
\hline Pterostichus hudsonicus LeC.* & 7-16 & 9 & -38 to -20 & 18 \\
\hline Pterostichus kotzebuei Ball* & $2.5-17$ & 14.5 & -45 to -12.5 & 32.5 \\
\hline
\end{tabular}


TABLE I

Mutual Climatic Range estimates for beetle species found in late Pleistocene fossil assemblages from Alaska and the Yukon Territory

\begin{tabular}{|c|c|c|c|c|}
\hline Species & $\operatorname{TMAX}\left({ }^{\circ} \mathrm{C}\right)$ & TMAX range & $\operatorname{TMIN}\left({ }^{\circ} \mathrm{C}\right)$ & TMIN range \\
\hline Pterostichus mandibularoides Ball ${ }^{\star}$ & $7.5-16$ & 8.7 & -37.5 to -11.5 & 26 \\
\hline Pterostichus nivalis (Sahlb.)* & $2.5-15.5$ & 13 & -22 to -7 & 15 \\
\hline Pterostichus parasimilis Ball ${ }^{*}$ & $5.5-16.5$ & 11 & -40 to -11.5 & 28.5 \\
\hline Pterostichus pinguedineus (Eschz.)* & 7-15.5 & 8.5 & -38 to -15.5 & 22.5 \\
\hline Pterostichus similis Mann. & $5.5-15.5$ & 10 & -37.5 to -6.5 & 31 \\
\hline Pterostichus soperi Ball* & 7.5-17 & 9.5 & -40 to -15 & 25 \\
\hline Pterostichus tareumiut Ball* & 2.5 to 17.5 & 15 & -40 to -6.5 & 33.5 \\
\hline Pterostichus ventricosus (Eschz.)* & 6-15.5 & 9.5 & -39 to -1.5 & 37.5 \\
\hline Pterostichus vermiculosus Mén. ${ }^{*}$ & $7-14$ & 7 & -38 to -17 & 21 \\
\hline Agonum consimile (Gyll.) & $4-16$ & 12 & -41 to +1 & 42 \\
\hline Agonum exaratum (Mannh.) ${ }^{*}$ & 8-18 & 10 & -37 to -17 & 20 \\
\hline Agonum quinquepunctatum Mots. & $9.5-16.5$ & 7 & -39 to -1.5 & 37.5 \\
\hline Amara browni Lth.* & 11.5-15 & 3.5 & -33 to -26 & 7 \\
\hline Amara erratica (Duft.)* & $9.5-18$ & 8.5 & -35 to +0.5 & 35.5 \\
\hline Amara glacialis (Mannh.) & $5-16$ & 11 & -39.5 to +2 & 41.5 \\
\hline Amara hyperborea Dej. & $7-17.5$ & 10.5 & -38 to -6 & 32 \\
\hline Trichocellus mannerheimii (Sahlb.) & $6-15.5$ & 9.5 & -39.5 to -17.5 & 22 \\
\hline Cymindis unicolor Kby. & $5-23$ & 17 & -41 to +4.5 & 45.5 \\
\hline \multicolumn{5}{|l|}{ Dytiscidae } \\
\hline Colymbetes dolobratus (Payk.) & $4.5-15$ & 10.5 & -41 to -9.5 & 31.5 \\
\hline Hydroporus lapponum Gyll. & $4-15.5$ & 11.5 & -42 to -5 & 37 \\
\hline Hydroporus morio Aube & $5.5-18$ & 12.5 & -41.5 to -3 & 38.5 \\
\hline Hydroporus notablis LeC. & $8-20.5$ & 12.5 & -35.5 to 0 & 35.5 \\
\hline Hydroporus polaris Fall & $4-16$ & 12 & -41.5 to -14 & 27.5 \\
\hline Agabus arcticus Payk. & 7-17.5 & 10.5 & -37.5 to +0.5 & 38 \\
\hline Agabus inscriptus Crotch & $6.5-20.5$ & 14 & -37.5 to +1.5 & 39 \\
\hline Agabus moestus Curtis & $5-17.5$ & 12.5 & -41 to -9.5 & 31.5 \\
\hline Ilybius angustior Gyll & $7-22.5$ & 15.5 & -37.5 to +2.5 & 40 \\
\hline \multicolumn{5}{|l|}{ Staphylinidae } \\
\hline Arpedium brachypterum (Grav.) & $7-16$ & 9 & -35 to +3 & 38 \\
\hline Acidota quadrata (Zett.) & $7-20.5$ & 13.5 & -37 to +0.5 & 37.5 \\
\hline Olophrum boreale (Payk.) & $9-20.5$ & 11.5 & -36 to -1.5 & 37.5 \\
\hline Olophrum latum Mäkl. & $8.5-16.5$ & 8 & -36 to -0.5 & 36.5 \\
\hline Tachinus instabilis Mäkl.* & 8-14.5 & 6.5 & -33 to -6 & 27 \\
\hline Mycetoporus nigrans Mäkl & $6.5-21$ & 14.5 & -38 to +4.5 & 42.5 \\
\hline \multicolumn{5}{|l|}{ Silphidae } \\
\hline Thanatophilus coloradensis Wickh. & $10.5-15$ & 4.5 & -34 to -10 & 24 \\
\hline Silpha trituberculata Kby.* & $8-20$ & 12 & -37.5 to -11 & 26.5 \\
\hline \multicolumn{5}{|l|}{ Scarabaeidae } \\
\hline Aphodius congregatus Mannh. & $6.5-18$ & 11.5 & -25 to +2.5 & 27.5 \\
\hline Mean values & $6.8-18.9$ & 12.1 & -37.3 to -6.8 & 30.5 \\
\hline \multicolumn{5}{|c|}{ Boreal, montane, and temperate species } \\
\hline \multicolumn{5}{|c|}{ Carabidae } \\
\hline Carabus maeander Fisch. & $9-22.5$ & 13.5 & -36 to +4.75 & 31.25 \\
\hline Pelophila rudis (LeC.) & $11.5-16.5$ & 5 & -33 to -8.5 & 24.5 \\
\hline Opisthius richardsoni Kby. & $10-20.75$ & 10.75 & -35.5 to +3 & 38.5 \\
\hline Notiophilus intermedius Lth. & $12.5-19.5$ & 7 & -29 to -5.25 & 23.75 \\
\hline Notiophilus semistriatus Say & $9.5-27$ & 17.5 & -36.5 to +8 & 44.5 \\
\hline Notiophilis sylvaticus Eschz. & $9.5-19$ & 9.5 & -20.5 to +5.25 & 25.75 \\
\hline Blethisa multipunctata Fisch. & $10.5-20.5$ & 10 & -35 to -2 & 33 \\
\hline
\end{tabular}


TABLE I

Mutual Climatic Range estimates for beetle species found in late Pleistocene fossil assemblages from Alaska and the Yukon Territory

\begin{tabular}{|c|c|c|c|c|}
\hline Species & $\operatorname{TMAX}\left({ }^{\circ} \mathrm{C}\right)$ & TMAX range & $\operatorname{TMIN}\left({ }^{\circ} \mathrm{C}\right)$ & TMIN range \\
\hline Elaphrus lapponicus Gyll. & $10.5-16.25$ & 5.75 & -35 to -1.75 & 33.25 \\
\hline Loricera pilicornis (Fab.) & $11-26$ & 15 & -35.5 to +2 & 37.5 \\
\hline Dyschirius aeneolus Lec. & $11.5-20.5$ & 9 & -33 to -2.75 & 30.25 \\
\hline Dyschirius integer LeC. & $11-27$ & 16 & -35 to +5 & 40 \\
\hline Dyschirius laevifasciatus Horn & $8.5-19.5$ & 11 & -28 to -7 & 21 \\
\hline Dyschirius subarcticus Lth. & $11-16.5$ & 5.5 & -34 to -1.5 & 32.5 \\
\hline Patrobus foveocollis (Eschz.) & $8.25-20.5$ & 12.25 & -35.75 to -6.5 & 29.25 \\
\hline Patrobus septentrionis Dej. & 8-19 & 11 & -37 to -6 & 31 \\
\hline Patrobus stygicus Chd. & $7-20.75$ & 13.75 & -39.75 to -1.25 & 38.5 \\
\hline Trechus apicalis Mots. & $7.5-22.5$ & 15 & -37 to +2.5 & 39.5 \\
\hline Trechus chalybeus Dej. & $8.75-27.75$ & 19 & -29.75 to +14.25 & 44 \\
\hline Bembidion breve Mots. & $7-20.5$ & 13.5 & -31.25 to +0.5 & 31.75 \\
\hline Bembidion concolor (Kby.) & $11-20.75$ & 9.75 & -33.75 to +1.75 & 35.5 \\
\hline Bembidion concretum Csy. & $12-23$ & 11 & -34 to +1 & 35 \\
\hline Bembidion convexulum Hayw. & $7-19$ & 12 & -37 to +5 & 42 \\
\hline Bembidion fortestriatum (Mots.) & $11.5-22$ & 10.5 & -34 to +3.5 & 37.5 \\
\hline Bembidion gratiosum Csy. & 7.5-17.5 & 10 & -35.5 to -0.5 & 35 \\
\hline Bembidion intermedium (Kby.) & $12-20.5$ & 8.5 & -29.5 to -2.5 & 27 \\
\hline Bembidion morulum LeC. & $8.75-15.5$ & 6.75 & -36.75 to -8 & 28.75 \\
\hline Bembidion quadrimaculatum (LeC.) & $10.5-27.5$ & 17 & -33.5 to +9.5 & 43 \\
\hline Pterostichus adstrictus Eschz. & 7-25.5 & 18 & -38 to +7 & 45 \\
\hline Pterostichus chipewyan Ball & $11-18$ & 7 & -37 to -18 & 19 \\
\hline Pterostichus gerstlensis Ball* & $13-17$ & 4 & -33 to -22 & 11 \\
\hline Pterostichus punctatissimus (Rand.) & $10-19$ & 9 & -33.75 to -5 & 28.75 \\
\hline Agonum gratiosum (Mannh.) & $12-26$ & 14 & -34 to -5.5 & 28.5 \\
\hline Agonum picicornoides Lth. & $12-20.25$ & 8.25 & -28 to -3.25 & 24.75 \\
\hline Agonum thoreyi Dej. & $10.5-26.5$ & 16 & -35.5 to +6.5 & 42 \\
\hline Amara discors Kby. & $8.5-27.5$ & 19 & -35.5 to +5.5 & 41 \\
\hline Amara laevipennis Kby. & $9-21$ & 12 & -35 to +0.5 & 35.5 \\
\hline Amara quenseli (Schönhr.) & $7-22$ & 15 & -37.75 to +6 & 43.75 \\
\hline Amara sinuosa (Csy.) & $9-20$ & 11 & -36 to +3 & 39 \\
\hline Harpalus amputatus Say & $9.5-24.5$ & 15 & -35.5 to +2.25 & 37.75 \\
\hline Harpalus nigritarsus Sahlb. & $6.25-23.75$ & 17.5 & -38.75 to +6.5 & 45.25 \\
\hline Bradycellus lecontei Csiki & $7.5-21.75$ & 14.25 & -37.25 to +0.25 & 37.5 \\
\hline Chlaenius niger Rand. & $11.5-26$ & 14.5 & -31.75 to +7.25 & 39 \\
\hline \multicolumn{5}{|l|}{ Dytiscidae } \\
\hline Agabus colymbus Leech & $10.5-13.5$ & 3 & -37 to -29 & 8 \\
\hline Hydroporus griseostriatus (DeG.) & $9-24$ & 15 & -34 to +14 & 48 \\
\hline Ilybius discidens Sharp & $7-23$ & 16 & -39 to +4 & 43 \\
\hline \multicolumn{5}{|l|}{ Hydrophilidae } \\
\hline Cercyon herceus Smet. & $11.75-28.5$ & 16.75 & -26.75 to +3.5 & 30.25 \\
\hline Cercyon marinus Ths. & $9.5-23$ & 13.5 & -35 to +3.5 & 38.5 \\
\hline Helophorus oblongus LeC. & $7-24.5$ & 17.5 & -37.25 to +4 & 41.25 \\
\hline Ochthebius kaszabi Janss. & $10-21$ & 11 & -34 to -0.5 & 33.5 \\
\hline Ochthebius marinus (Payk.) & $9.75-32$ & 22.25 & -29.75 to +7 & 36.75 \\
\hline Hydraena angulicollis Notm. & $13.5-24$ & 10.5 & -29.25 to -2 & 27.25 \\
\hline \multicolumn{5}{|l|}{ Staphylinidae } \\
\hline Pycnoglypta lurida (Gyll.) & $9.5-24$ & 14.5 & -34.5 to +4.75 & 39.25 \\
\hline Acidota crenata (Fab.) & $9-24$ & 15 & -31.5 to +4 & 35.5 \\
\hline Boreaphilus henningianus Sahlb. & $7-23.5$ & 16.5 & -36.5 to -1.5 & 35 \\
\hline
\end{tabular}


TABLE I

Mutual Climatic Range estimates for beetle species found in late Pleistocene fossil assemblages from Alaska and the Yukon Territory

\begin{tabular}{|c|c|c|c|c|}
\hline Species & $\operatorname{TMAX}\left({ }^{\circ} \mathrm{C}\right)$ & TMAX range & $\operatorname{TMIN}\left({ }^{\circ} \mathrm{C}\right)$ & TMIN range \\
\hline Quedius fellmani (Zett.) & $9-19.5$ & 10.5 & -35 to +1 & 36 \\
\hline Quedius fulvicollis (Steph.) & $8.5-23$ & 14.5 & -31.5 to +5 & 36.5 \\
\hline Quedius pediculus (Nordm.) & $8-19$ & 11 & -22 to +2 & 24 \\
\hline Tachinus frigidus Er. & 8-19.5 & 11.5 & -36.5 to +9 & 45.5 \\
\hline Tachyporus borealis Campbl. & $8.5-22.5$ & 14 & -35.5 to +5.5 & 41 \\
\hline Tachyporus canadensis Campbl. & $10-23.75$ & 13.75 & -34 to +6.25 & 40.25 \\
\hline Tachyporus nimbicola Campbl. & 8-22 & 14 & -35 to +2.5 & 37.5 \\
\hline Tachyporus rulomus Blackwldr. & $6.25-20$ & 13.75 & -40.25 to +1 & 41.25 \\
\hline Gymnusa atra Csy & $11.5-23$ & 11.5 & -31.5 to +5 & 36.5 \\
\hline \multicolumn{5}{|l|}{ Micropeplidae } \\
\hline Micropeplus tesserula Curtis & $11.5-23$ & 11.5 & -28.5 to +11.5 & 40 \\
\hline Micropeplus sculptus LeC. & $15.5-29$ & 13.5 & -19 to +9 & 28 \\
\hline Micropeplus laticollis Mäkl. & $9.25-19.5$ & 10.25 & -25.75 to -1.5 & 24.25 \\
\hline \multicolumn{5}{|l|}{ Scarabaeidae } \\
\hline Aegialia lacustris LeC. & $9.5-22$ & 12.5 & -25.5 to +5 & 30.5 \\
\hline Aphodius distinctus (Mull.) & $9.5-27$ & 17.5 & -33 to +8.5 & 41.5 \\
\hline Mean values & $9.7-21.5$ & 11.8 & -33.6 to +0.6 & 34.2 \\
\hline
\end{tabular}

* Species with Beringian distribution pattern

paleoclimatic reconstructions, using the MCR method, and the original faunal descriptions can be found in the literature cited in Elias (1996) and Elias et al. (1996a).

While it is tempting to speculate on endemism of beetle species in the Beringian fauna, previous fossil studies have shown that modern or even late Pleistocene ranges of species may not necessarily reflect the total history of a species' movements. In the strictest meaning of the word, a species is considered endemic to a given region only if it has existed exclusively in that region since its evolution. Many if not most of the beetle species found in Pleistocene assemblages from Beringia have existed for hundreds of thousands or even millions of years (Matthews, 1977). Some of these species might appear to be endemic to some part of Beringia, based on their modern range, but the fossil record belies this idea. For instance, the rove beetle, Micropeplus hoogendorni, is known today only from specimens in northeastern Siberia, but it has been found as a fossil in middle Pleistocene deposits from Europe and from Pliocene deposits in Alaska (Elias, 1994). The fossil record can provide evidence about the past ranges of species, but only within limits. It usually provides only 'snapshots' of a given species' range during brief segments of its history.

\section{STUDY SITES}

For this study, I selected 25 fossil sites in Alaska, the Yukon Territory, and the formerly-exposed continental shelf regions of the Bering and Chukchi seas (Figure 1; Tables II and III). These sites contain fossil assemblages spanning the interval from just prior to the last interglacial period to the end of the last glaciation (ca. $10000{ }^{14} \mathrm{C} \mathrm{yr}$ BP.). Beyond that time, Beringia ceased to exist because the Bering Land Bridge was inundated by sea water. There are older Pleistocene deposits in Alaska and the Yukon that have yielded insect fossil assemblages, but the dating of these older assemblages is problematic at best. The oldest samples discussed here are stratigraphically linked to the deposition of the Old Crow tephra, an ash layer deposited in many regions of Alaska and the Yukon approximately 140000 years ago (Preece et al., 1999). Most of the sites discussed here yielded fossil assemblages from only one brief interval of time. Some sites, such as localities at Hungry Creek, the Nushagak Lowland, the Old Crow River, and the Noatak River, yielded a series of discrete organic units representing two or more time intervals. None of the sites yielded fossils representing continuous organic deposition through long periods of time (i.e., tens of thousands or hundreds of thousands of years). The original descriptions of the fossil assemblages are referenced in Table III.

Many of the study sites are cutbank exposures of large rivers, such as the Porcupine and Old Crow rivers in the Yukon, and the Noatak, Foraker, Toklat, and Kuskokwim rivers in Alaska. Other sites, such as the Nushagak Lowland sites, are coastal bluff exposures. Most of the organic deposits from which the fossil insects were extracted accumulated in ponds, lakes, or slack-water fluvial environments. The taphonomy of the fossil assemblages exerts considerable influence on insect faunal composition (Morlan and Matthews, 1983). In spite of the fact that all of the fossil assemblages represent water-lain deposits, the majority of specimens in most assemblages represent terrestrial species, and very few assemblages are dominated by aquatic taxa. 


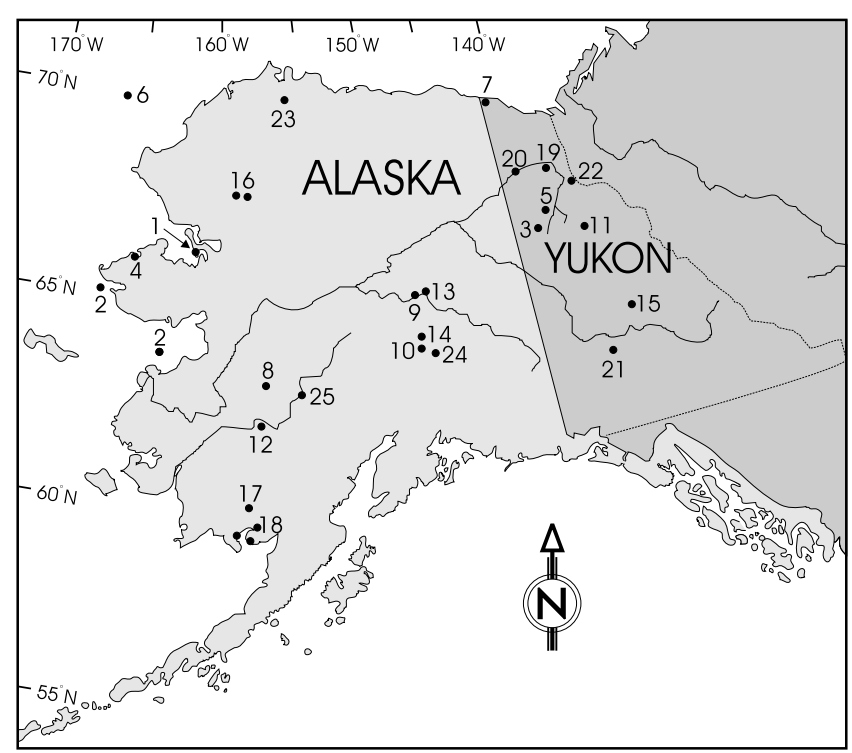

FIGURE 1. Map of Alaska and the Yukon Territory, showing location of fossil sites discussed in text. Site numbers correspond to those shown in Table III. Numbers 2, 16, and 18 have multiple localities, as discussed in text.

Carte de l'Alaska et du Territoire du Yukon montrant la localisation des sites fossiles dont on parle dans le texte. Les numéros de sites correspondent à ceux du tableau III. Les numéros 2, 16 et 18 correspondent à de multiples localités, tel qu'indiqué dans le texte.

\section{RESULTS}

The Late Pleistocene assemblages from the study region yielded 147 species of predators and scavengers (Table I). These beetle species fall into three zoogeographic categories, based on their modern distributions: arctic and alpine, boreo-arctic or boreo-alpine, and boreal to temperate. The arctic and alpine species comprise the smallest component (14 species, or $10 \%$ ) of the fossil assemblages, even though these beetles dominate many fossil assemblages from glacial periods. The boreo-arctic and boreo-alpine species comprise 65 species, or $44 \%$ of the total number of predatory and scavenging species found in the fossil assemblages. Some of these species were found in glacial as well as interglacial and interstadial fossil assemblages, presumably because of their tolerance of cold climates. The third group, those with modern distributions in the boreal forest, montane forest, or temperate regions, comprise 68 species, or $46 \%$ of the total.

\section{THERMAL REQUIREMENTS OF THE BERINGIAN BEETLE FAUNA}

Not surprisingly, the arctic and alpine group is the most cold-adapted of the three. The mean TMAX values for the arctic and alpine group fall within $5.7-12.4^{\circ} \mathrm{C}$, a range of $6.7^{\circ} \mathrm{C}$. The overall range of TMAX represented by the climate envelopes of the arctic and alpine species is somewhat greater, from 3 to $16^{\circ} \mathrm{C}$ (Fig. 2). The mean TMIN values for this group fall within -36.8 to $-18.1^{\circ} \mathrm{C}$, a range of $18.7^{\circ} \mathrm{C}$. The overall range of TMIN values for this group is -39.5 to $-5.5^{\circ} \mathrm{C}$. Of the arctic and alpine species, four ( $29 \%)$ are stenothermic, ten $(71 \%)$ are mesothermic, and none are eurythermic. The small number of arctic and alpine species and their great degree of climatic specificity make sense ecologically. The survival of insects in cold climates requires unusual physiological and behavioral adaptations (Danks, 1981a). There are relatively few species of beetles adapted to life in arctic and alpine habitats. A few cosmopolitan species (species adapted to a wide range of temperatures) are found in arctic and alpine regions, but for the most part these regions are inhabited by taxa adapted to cold climates. Danks (1981b) discussed the distribution patterns of arctic arthropods, and reported that there are several species with cosmopolitan ranges, but that these include chiefly soil-dwelling taxa, such as Collembola (springtails). Of the 78 species of arctic ground beetles listed in Danks (1981b), none is cosmopolitan. None of the 66 species of predators and scavengers in other beetle families listed in Danks (1981b) (Haliplidae, Dytiscidae, Hydrophilidae, Silphidae, Staphylinidae, and Coccinellidae) has a cosmopolitan range.

The fossil assemblages yielded 65 species of boreo-arctic beetles. As expected, most of these species are adapted to a broader range of summer temperatures than the arctic and alpine group. The mean TMAX values for this group fall within $6.8-18.9^{\circ} \mathrm{C}$, a range of $12.1^{\circ} \mathrm{C}$. The overall range of TMAX values for this group is substantially greater, from 2.5 to $22.5^{\circ} \mathrm{C}$. The mean TMIN values for this group fall within -37.3 to $-6.8^{\circ} \mathrm{C}$, a range of $30.5^{\circ} \mathrm{C}$. The overall range of TMIN values for this group is from -45 to $4.5^{\circ} \mathrm{C}$. Winter temperatures in the boreal region are often extremely cold, and not much different than those found in the Arctic. However, summer temperatures are generally much warmer in the boreal region. Of the boreo-arctic species in the fossil assemblages, four (6\%) are stenothermic, $23(35 \%)$ are mesothermic, and $39(57 \%)$ are eurythermic.

There were 68 species of beetles whose modern populations have either boreal or temperate distributions. Among these species, only two (3\%) are stenothermic, $18(23 \%)$ are mesothermic, and $57(74 \%)$ are eurythermic. The mean TMAX values for this group fall within $9.7-21.5^{\circ} \mathrm{C}$, a range of $11.8^{\circ} \mathrm{C}$. The overall range of TMAX values for this group is from 6.25 to $29^{\circ} \mathrm{C}$ (Fig. 2). The mean TMIN values for this group fall within -33.6 to $0.6^{\circ} \mathrm{C}$, a range of $34.2^{\circ} \mathrm{C}$. The overall range of TMIN values for this group is from -40.25 to $14.25^{\circ} \mathrm{C}$. Thus there is a differentiation in the climatic tolerances between the arctic and alpine group and the other two groups of beetles. The arctic and alpine species tend to have narrower climatic tolerances, whereas boreo-arctic and temperate species tend to have much broader climatic tolerances.

A plot of the range of TMAX and TMIN temperatures associated with the three distributional groups (Fig. 2) shows that there is considerable overlap between groups, although each of the three groups has a mean value distinct from the other two. The separation of mean values between groups is clearer for TMAX values than for TMIN. This observation is in keeping with the life histories of the beetles in the arctic, boreal, and temperate life zones. Most of these beetles are inactive during the winter months, or pass the winter as eggs, 
TABLE ॥

Quaternary fossil beetle species identified from Beringian sites

\begin{tabular}{|c|c|}
\hline Taxon & Sites $^{1}$ \\
\hline \multicolumn{2}{|l|}{ CARABIDAE } \\
\hline Carabus chamissonis Fisch. & $\mathrm{EC}, \mathrm{HC}, \mathrm{PR}, \mathrm{RR}$ \\
\hline Carabus maeander Fisch. & $\mathrm{NL}$ \\
\hline Carabus taedatus Fabr. & $\mathrm{NL}$ \\
\hline Carabus truncaticollis Eschz. & $\mathrm{BB}, \mathrm{CD}, \mathrm{EC}, \mathrm{HC}, \mathrm{NL}, \mathrm{RR}$ \\
\hline Pelophila borealis (Payk.) & $\mathrm{CB}, \mathrm{CD}, \mathrm{MV}$ \\
\hline Pelophila rudis (LeC.) & $\mathrm{HC}$ \\
\hline Nebria gebleri Dej. & NL \\
\hline Nebria metallica Fisch. & NL,NY \\
\hline Nebria nivalis (Payk.) & NL \\
\hline Opisthius richardsoni Kby. & OC \\
\hline Notiophilus borealis Harr. & $\mathrm{CD}, \mathrm{EC}, \mathrm{NL}$ \\
\hline Notiophilus intermedius Lth. & $\mathrm{NL}$ \\
\hline Notiophilus semistriatus Say & $\mathrm{CD}, \mathrm{EC}, \mathrm{FR}, \mathrm{TO}$ \\
\hline Notiophilis sylvaticus Eschz. & $\mathrm{HC}$ \\
\hline Diacheila arctica Gyll. & HL,NY,UKL \\
\hline Diacheila polita (Fald.) & $\begin{array}{l}\mathrm{BS}, \mathrm{CB}, \mathrm{CD}, \mathrm{EC}, \mathrm{HC}, \mathrm{HL}, \mathrm{NL} \text {, } \\
\mathrm{NR}, \mathrm{NY}, \mathrm{OC}, \mathrm{RR}, \mathrm{UKL}\end{array}$ \\
\hline Blethisa catenaria Brown & $\mathrm{CB}, \mathrm{HL}$ \\
\hline Blethisa multipunctata Fisch. & $\mathrm{CB}$ \\
\hline Elaphrus lapponicus Gyll. & $\mathrm{CB}, \mathrm{CD}, \mathrm{NL}, \mathrm{PR}$ \\
\hline Elaphrus parviceps VD. & $\mathrm{HL}, \mathrm{MV}$ \\
\hline Elaphrus tuberculatus Mäkl. & $\mathrm{HL}$ \\
\hline Loricera pilicornis (Fab.) & NL \\
\hline $\begin{array}{l}\text { Dyschirius aeneolus } \\
\text { (frigidus) LeC. }\end{array}$ & $\mathrm{CD}, \mathrm{NL}$ \\
\hline Dyschirius integer LeC. & NL \\
\hline $\begin{array}{l}\text { Dyschirius laevifasciatus } \\
\text { Horn }\end{array}$ & $\mathrm{CB}$ \\
\hline
\end{tabular}

Dyschirius melancholicus (nigricornis) Putz.

Dyschirius subarcticus Lth.

Patrobus foveocollis (Eschz.)

Patrobus septentrionis Dej.

Patrobus stygicus Chd.

Trechus apicalis Mots.

Trechus chalybeus Dej.

Asaphidion alaskanum

Wickh.

Bembidion arcticum Lth. EC

Bembidion concolor Kby. $\quad \mathrm{CB}$

Bembidion concretum Csy. $\quad \mathrm{CB}, \mathrm{NL}, \mathrm{NY}$

Bembidion convexulum

Hayw.

Bembidion dauricum (Mots.)

Bembidion fortestriatum

(Mots.)

Bembidion grapii Gyll.

Bembidion gratiosum Csy.

Bembidion hastii Sahlb.

\section{BS,CD,EC,FR,NL,NR,NY,OC,UKL}

OC

$\mathrm{CB}, \mathrm{HL}, \mathrm{NL}, \mathrm{OC}$

$\mathrm{NL}$

HC,HL,NL,NY

$\mathrm{NL}$

$\mathrm{PR}, \mathrm{RR}, \mathrm{UKL}$

CB

\section{CB,EC,PR}

NL,NY

$\mathrm{BS}, \mathrm{CB}, \mathrm{CS}, \mathrm{EC}, \mathrm{HC}, \mathrm{NL}, \mathrm{NY}$

$\mathrm{NL}$

MV
TABLE ॥

Quaternary fossil beetle species identified from Beringian sites

\begin{tabular}{ll}
\hline \multicolumn{1}{c}{ Taxon } & \multicolumn{1}{c}{ Sites $^{1}$} \\
\hline $\begin{array}{l}\text { Bembidion breve (incertum) } \\
\text { (Mots.) }\end{array}$ & $\mathrm{NL}$ \\
$\begin{array}{l}\text { Bembidion intermedium } \\
\text { (Kby.) }\end{array}$ & $\mathrm{CB}$ \\
$\begin{array}{l}\text { Bembidion morulum LeC. } \\
\text { Bembidion quadrimaculatum } \\
\text { (LeC.) }\end{array}$ & $\mathrm{HC}, \mathrm{OC}, \mathrm{RR}$ \\
$\begin{array}{l}\text { Bembidion sordidum (Kby.) } \\
\text { Bembidion transparens } \\
\text { (Gebl.) }\end{array}$ & $\mathrm{HC}, \mathrm{MV}$ \\
$\begin{array}{l}\text { Bembidion umiatense Lth. } \\
\text { Stereocerus (Pterostichus) } \\
\text { haematopus Dej. }\end{array}$ & $\mathrm{CD}, \mathrm{HC}, \mathrm{MV}, \mathrm{OC}, \mathrm{RR}$ \\
\end{tabular}

Pterostichus adstrictus

Eschz.

Pterostichus agonus Horn

Pterostichus arcticola(Chd.)

Pterostichus auriga Ball

Pterostichus bryanti VD

Pterostichus brevicornis

(Kby.)

Pterostichus caribou Ball

Pterostichus chipewyan Ball

Pterostichus circulosus Lth.

Pterostichus costatus (Mén.)

Pterostichus empetricola

(Dej.)

Pterostichus gerstlensis Ball

Pterostichus hudsonicus

LeC.

Pterostichus kotzebuei Ball

Pterostichus

mandibularoides Ball

Pterostichus nearcticus

(Lth.)

Pterostichus nivalis (Sahlb.)

Pterostichus parasimilis Ball

Pterostichus pinguedineus

(Eschz.)

Pterostichus punctatissimus

(Rand.)

Pterostichus similis Mann.

Pterostichus soperi Ball

Pterostichus sublaevis

(Sahlb.)

Pterostichus tareumiut Ball

Pterostichus ventricosus

(Eschz.)

Pterostichus vermiculosus

Mén.

Agonum consimile (Gyll.)

$\mathrm{CB}, \mathrm{NL}$

$\mathrm{BS}, \mathrm{CD}, \mathrm{HL}, \mathrm{NL}, \mathrm{NY}$

$\mathrm{HL}, \mathrm{NL}, \mathrm{UKL}$

$\mathrm{CD}, \mathrm{EC}$

$\mathrm{CD}, \mathrm{HL}$

$\mathrm{BS}, \mathrm{CB}, \mathrm{CD}, \mathrm{EC}, \mathrm{FR}, \mathrm{HC}, \mathrm{HL}, \mathrm{MV}, \mathrm{NL}, \mathrm{N}$ R,NY,OC,PR,RC,TO,UKL

$B S, C C, E C, H C, M V, N L, O C, P R, U K L$

EC

NL,NY

$\mathrm{CB}, \mathrm{CD}, \mathrm{PR}$

$\mathrm{HL}, \mathrm{NL}, \mathrm{NR}$

CB,EC

$\mathrm{CD}, \mathrm{HC}, \mathrm{OC} ?, \mathrm{RC}$

CB,CD,EC,HL,NL,NY,OC,PR

CD,EC,MC,NR,PR

BB,CD,HC,OC?,PR

$\mathrm{BS}, \mathrm{CB}, \mathrm{CD}, \mathrm{EC}, \mathrm{HL}, \mathrm{LB}, \mathrm{MV}, \mathrm{NL}, \mathrm{NR}, \mathrm{P}$ $\mathrm{R}, \mathrm{RC}, \mathrm{UKL}$

$\mathrm{CB}, \mathrm{CD}, \mathrm{EC}, \mathrm{HL}, \mathrm{NL}, \mathrm{PR}$

$\mathrm{BB}, \mathrm{CB}, \mathrm{CD}, \mathrm{EC}, \mathrm{HC}, \mathrm{HL}, \mathrm{MV}, \mathrm{NL}, \mathrm{NY}, \mathrm{O}$ $\mathrm{C}, \mathrm{PR}$

$\mathrm{HC}$

$\mathrm{CD}, \mathrm{EC}, \mathrm{HC}, \mathrm{HL}, \mathrm{NL}$ $\mathrm{CB}, \mathrm{CD}, \mathrm{EC}, \mathrm{PR}$

$\mathrm{BB}, \mathrm{BS}, \mathrm{CD}, \mathrm{HC}, \mathrm{HL}, \mathrm{OC}, \mathrm{PR}$

CB,CD,EC,HL,NL,NY,OC,PR,UKL

BB,CB,CD,EC,HC,OC,PR,RR

$\mathrm{CD}, \mathrm{HC}, \mathrm{OC}, \mathrm{PR}, \mathrm{RR}$

CB

CD 
TABLE II

Quaternary fossil beetle species identified from Beringian sites

\begin{tabular}{|c|c|}
\hline Taxon & Sites $^{1}$ \\
\hline Agonum gratiosum (Mannh.) & IB,HL,NL,NY,TO \\
\hline Agonum picicornoides Lth. & $\mathrm{NL}$ \\
\hline $\begin{array}{l}\text { Agonum quinquepunctatum } \\
\text { Mots. }\end{array}$ & $\mathrm{CB}, \mathrm{EC}, \mathrm{HC}, \mathrm{HL}, \mathrm{MC}$ \\
\hline Agonum thoreyi Dej. & NL? \\
\hline Amara alpina (Payk.) & $\begin{array}{l}\mathrm{BB}, \mathrm{CB}, \mathrm{CD}, \mathrm{EC}, \mathrm{HC}, \mathrm{HL}, \mathrm{NL}, \mathrm{OC}, \mathrm{PR}, \mathrm{R} \\
\mathrm{R}\end{array}$ \\
\hline Amara bokeri Csiki & $\mathrm{CB}, \mathrm{CD}, \mathrm{HC}, \mathrm{OC}, \mathrm{PR}$ \\
\hline Amara browni Lth. & $\mathrm{CD}$ \\
\hline Amara discors Kby. & TO \\
\hline Amara glacialis (Mannh.) & $\mathrm{BB}, \mathrm{HC}, \mathrm{MV}, \mathrm{PR}$ \\
\hline Amara hyperborea Dej. & CD \\
\hline Amara laevipennis Kby. & TO \\
\hline Amara quelseli (Schönhr.) & $\mathrm{HC}$ \\
\hline Amara sinuosa (Csy.) & NL,NY \\
\hline Harpalus amputatus Say & $\mathrm{CD}, \mathrm{HC}, \mathrm{MV}, \mathrm{OC}, \mathrm{PR}$ \\
\hline Harpalus nigritarsus Sahlb. & CD \\
\hline $\begin{array}{l}\text { Trichocellus mannerheimi } \\
\text { (Sahlb.) }\end{array}$ & $\mathrm{CB}, \mathrm{CD}, \mathrm{HC}, \mathrm{MV}, \mathrm{NL}, \mathrm{OC}, \mathrm{PR}, \mathrm{RR}$ \\
\hline Bradycellus lecontei Csiki & CB \\
\hline Chlaenius niger Rand. & $\mathrm{HC}$ \\
\hline Cymindis unicolor Kby. & NU \\
\hline \multicolumn{2}{|l|}{ DYTISCIDAE } \\
\hline Agabus arcticus Payk. & HL,NR \\
\hline Agabus colymbus Leech & HL,NY \\
\hline Agabus moestus Curtis & BS \\
\hline Ilybius discidens Sharp & HL,NY \\
\hline $\begin{array}{l}\text { Colymbetes dolobratus } \\
\text { (Payk.) }\end{array}$ & BS \\
\hline $\begin{array}{l}\text { Hydroporus griseostriatus } \\
\text { (DeG.) }\end{array}$ & $\mathrm{HL}$ \\
\hline Hydroporus polaris Fall & $\mathrm{CS}, \mathrm{HL}$ \\
\hline \multicolumn{2}{|l|}{ HYDROPHILIDAE } \\
\hline Cercyon herceus Smet. & $\mathrm{HC}$ \\
\hline Cercyon marinus Ths. & $\mathrm{CB}, \mathrm{CL}$ \\
\hline Helophorus oblongus LeC. & CB \\
\hline $\begin{array}{l}\text { Helophorus splendidus Sahlb. } \\
\text { HYDRAENIDAE }\end{array}$ & $\mathrm{BB}, \mathrm{BP}, \mathrm{CD}, \mathrm{CS}, \mathrm{OC}, \mathrm{PR}, \mathrm{RR}$ \\
\hline Hydraena angulicollis Notm. & HL,NY \\
\hline Ochthebius marinus (Payk.) & $\mathrm{CB}$ \\
\hline Ochthebius kaszabi Janss. & CB \\
\hline \multicolumn{2}{|l|}{ STAPHYLINIDAE } \\
\hline $\begin{array}{l}\text { Megarthrus sinuatincollis } \\
\text { Boisd. }\end{array}$ & $C D$ \\
\hline $\begin{array}{l}\text { Arpedium brachypterum } \\
\text { (Grav.) }\end{array}$ & $\mathrm{BS}, \mathrm{CD}, \mathrm{CS}, \mathrm{NR}$ \\
\hline $\begin{array}{l}\text { Eucnecosum brunnescens } \\
\text { Sahlb. }\end{array}$ & TR \\
\hline Olophrum boreale (Payk.) & $\mathrm{CB}, \mathrm{FR}, \mathrm{HC}, \mathrm{HL}, \mathrm{TO}, \mathrm{UKL}$ \\
\hline Olophrum consimile Gyll. & $\mathrm{CB}, \mathrm{FR}, \mathrm{HL}, \mathrm{NY}, \mathrm{RR}, \mathrm{TO}, \mathrm{TR}$ \\
\hline
\end{tabular}

TABLE ॥

Quaternary fossil beetle species identified from Beringian sites

\begin{tabular}{|c|c|}
\hline Taxon & Sites $^{1}$ \\
\hline Olophrum latum Mäkl. & $\begin{array}{l}\mathrm{CB}, \mathrm{CL}, \mathrm{HC}, \mathrm{HL}, \mathrm{NR}, \mathrm{NY}, \mathrm{PR}, \mathrm{RC}, \mathrm{RR}, \mathrm{T} \\
\mathrm{R}, \mathrm{UKL}\end{array}$ \\
\hline Olophrum rotundicolle Sahlb. & $\mathrm{CB}, \mathrm{FR}, \mathrm{HC}, \mathrm{HL}, \mathrm{NY}$ \\
\hline Pycnoglypta lurida (Gyll.) & $\mathrm{BS}, \mathrm{CS}, \mathrm{TR}$ \\
\hline Acidota crenata (Fab.) & HL,NY \\
\hline Acidota quadrata (Zett.) & HL,NY \\
\hline $\begin{array}{l}\text { Boreaphilus henningianus } \\
\text { Sahlb. }\end{array}$ & CB,CD,HL,NY,PR \\
\hline $\begin{array}{l}\text { Holoboreaphilus } \\
\text { nordenskioeldi Mäkl. }\end{array}$ & BS,CC,CS,HL,NL,NY,TR \\
\hline $\begin{array}{l}\text { Micralymma brevilingue } \\
\text { Schiodt. }\end{array}$ & $\begin{array}{l}\mathrm{BB}, \mathrm{CB}, \mathrm{CD}, \mathrm{EC}, \mathrm{HL}, \mathrm{NL}, \mathrm{NR}, \mathrm{PR}, \mathrm{RR}, \mathrm{T} \\
\mathrm{R}\end{array}$ \\
\hline Quedius fellmani (Zett.) & $\mathrm{HL}$ \\
\hline Quedius fulvicollis (Steph.) & $\mathrm{HL}$ \\
\hline Quedius pediculus (Nordm.) & $\mathrm{HL}$ \\
\hline Tachinus brevipennis Sahlb. & $\begin{array}{l}\text { BB,BP,BS,CB,CD,CS,EC,FR,HC,H } \\
\text { L,NR,NY,OC,PR,TR }\end{array}$ \\
\hline Tachinus frigidus Er. & $\mathrm{HL}$ \\
\hline Tachinus instabilis Mäkl. & MV \\
\hline Mycetoporus cf. nigrans Mäkl & BS \\
\hline Tachyporus borealis Campbl. & $\mathrm{HL}$ \\
\hline $\begin{array}{l}\text { Tachyporus canadensis } \\
\text { Campbl. }\end{array}$ & $\mathrm{HL}, \mathrm{NL}$ \\
\hline $\begin{array}{l}\text { Tachyporus nimbicola } \\
\text { Campbl. }\end{array}$ & $\mathrm{HL}$ \\
\hline Tachyporus rulomus Blkwldr & $\mathrm{BS}, \mathrm{HL}$ \\
\hline Gymnusa atra Csy. & BS \\
\hline \multicolumn{2}{|l|}{ MICROPEPLIDAE } \\
\hline Micropeplus laticollis Mäkl. & $\mathrm{HC}$ \\
\hline Micropeplus sculptus LeC. & $\mathrm{CB}$ \\
\hline Micropeplus tesserula Curtis & CB \\
\hline \multicolumn{2}{|l|}{ SILPHIDAE } \\
\hline Thanatophilus lapponicus (L.) & TR \\
\hline $\begin{array}{l}\text { Thanatophilus coloradensis } \\
\text { Wickh. }\end{array}$ & $\mathrm{CB}, \mathrm{CC}, \mathrm{PR}$ \\
\hline Silpha trituberculata Kby. & $\mathrm{EC}, \mathrm{HL}$ \\
\hline \multicolumn{2}{|l|}{ SCARABAEIDAE } \\
\hline Aegialia lacustris LeC. & HL,NY \\
\hline $\begin{array}{l}\text { Aphodius congregatus } \\
\text { Mannh. }\end{array}$ & $\mathrm{CC}$ \\
\hline Aphodius distinctus (Mull.) & $C D$ \\
\hline
\end{tabular}

1 Site Names: BB - Bluefish Basin; BP - Baldwin Peninsula, Alaska; BS - Bering Sea Shelf, Alaska; CB - Chi'jee's Bluff, Yukon Territory; CC - Colorado Creek, Alaska; CD - Cape Deceit, Alaska; CL Clarence Lagoon, Yukon Territory; CS - Chukchi Sea Shelf, Alaska; EC - Eva Creek, Alaska; FR - Foraker River, Alaska; HC - Hungry Creek, Yukon Territory; HL - Holitna Lowland, Alaska; IB - Isabella Basin, Alaska; LB - Landslide Bluff, Alaska; MV - Mayo Village, Yukon Territory; NL - Nushagak Lowland, Alaska; NR - Noatak River, Alaska; NY - Nuyakuk, Alaska; OC - Old Crow, Yukon Territory; PR Porcupine River, Yukon Territory; RC - Revenue Creek, Yukon Territory; RR - Rock River, Yukon Territory; TO - Toklat River, Alaska; TR - Titaluk River, Alaska; UKL - Upper Kuskokwim Lowland, Alaska. 
TABLE III

List of fossil insect sites and assemblage age ranges, Central and Eastern Beringia

\begin{tabular}{|c|c|c|}
\hline Site & Age Range $^{1}$ & Reference \\
\hline 1. Baldwin Peninsula, Alaska & $\mathrm{MW}$ & Hopkins et al., 1976 \\
\hline 2. Bering Sea Shelf, Alaska & LW & Elias et al., 1996b \\
\hline 3. Bluefish Basin, Yukon & LW & Matthews and Telka, 1997 \\
\hline 4. Cape Deceit, Alaska & LI, EW & Matthews, $1974 a$ \\
\hline 5. Chi'jee's Bluff, Yukon & LI & Matthews et al., 1990a \\
\hline 6. Chukchi Sea Shelf, Alaska & LW & Elias et al., 1996b \\
\hline 7. Clarence Lagoon, Yukon & LW & Matthews, $1975 a$ \\
\hline 8. Colorado Creek, Alaska & LGM & Elias, 1992a \\
\hline 9. Eva Creek, Alaska & LI, MW & Matthews, 1968 \\
\hline 10. Foraker River, Alaska & MW & Elias et al., 1996c \\
\hline 11. Hungry Creek, Yukon & LI,EW, MW & Hughes et al., 1981 \\
\hline 12. Holitna Lowland, Alaska & LI,MW,LGM,LW & Elias, 1992b \\
\hline 13. Isabella Basin, Alaska & MW,LW & Matthews, 1974b \\
\hline 14. Landslide Bluff, Alaska & LI & Waythomas et al., 1989 \\
\hline 15. Mayo Village, Yukon & MW & Matthews et al., 1990b \\
\hline 16. Noatak River, Alaska & PLI,LI & Elias et al., 1999b \\
\hline 17. Nushagak Lowland, Alaska & EW,MW,LGM,LW & Elias, 1992b \\
\hline 18. Nuyakuk, Alaska & $\mathrm{LI}$ & Elias and Short, 1992 \\
\hline 19. Old Crow, Yukon & PLI,LI,EW,MW,LW & Matthews, 1975b; Morlan and Matthews, 1983 \\
\hline 20. Porcupine River, Yukon & MW & Matthews, $1975 b$ \\
\hline 21. Revenue Creek, Yukon & LI & Matthews and Telka, 1997 \\
\hline 22. Rock River, Yukon & LGM & Matthews and Telka, 1997 \\
\hline 23. Titaluk River, Alaska & MW & Nelson and Carter, 1987 \\
\hline 24. Toklat River, Alaska & MW & Elias et al., 1996b \\
\hline 25. Upper Kuskokwim Lowland, Alaska & MW & Elias, 1992b \\
\hline
\end{tabular}

${ }^{1}$ Age range categories: PLI - Pre-Last Interglacial; LI - Last Interglacial; EW - Early Wisconsin; MW - Mid- Wisconsin; LGM - Last Glacial Maximum; LW - Late Wisconsin.

larvae, or pupae that are buried in the soil, beneath stones or logs, or in the mud at the bottom of streams, lakes, or ponds. This is particularly true of arctic and alpine and boreo-arctic species. Winter air temperatures in the arctic and boreal regions often fall to levels that are lethal for most beetle species. In order to avoid exposure to such temperatures, the beetle fauna of these regions spend the winter months in thermally buffered habitats, beneath leaf litter, stones, pond mud, or soil. These species are therefore adapted to the winter temperatures experienced in these sheltered habitats, not to the much colder air temperatures. As such these beetles are not very sensitive indicators of winter air temperatures. The same could be said of most other invertebrates and most plants, which are likewise more-or-less dormant during winter. Nevertheless, as shown by a study of predicted vs. observed TMIN from sites throughout North America (Elias et al., 1996a), beetle data provides at least a crude estimate of mean winter temperatures.

\section{ZOOGEOGRAPHY OF THE BERINGIAN FAUNA}

Among the arctic and alpine beetles found in the fossil assemblages, the majority (64\%) have Beringian distributions today. Their modern ranges are centered in Alaska and the Yukon Territory, although many species have spread eastward across the Northwest Territories during the Holocene (Scudder, 1979). Their dispersal farther east was blocked by Hudson Bay and late-lying ice in central and northern Québec. Typical of this group are several species in the Cryobius group of the ground beetle genus, Pterostichus. Many of the species in this group have both their fossil record and modern range entirely within Alaska and the Yukon Territory. Others in this group include the arctic rove beetles, Micralymma brevilingue and Tachinus brevipennis. It appears that these species may have never ranged outside of the Beringian region, although the absence of fossil evidence outside this region cannot be taken as evidence of their absence.

The arctic and alpine species not considered to have a Beringian distribution are an interesting group in their own right. The fossil record documents the fact that the ground beetles, Amara alpina, Blethisa catenaria, and Bembidion dauricum, had populations in Beringia during the late Pleistocene, but they also had populations in regions of the United States that were south of the continental ice sheets. Amara alpina has been found in Wisconsinan-age assemblages from Montana, lowa, and southern Québec. These assemblages span an interval from greater than 50000 to $11000 \mathrm{yr}$ BP. Blethisa catenaria has been found in Middle 
FIGURE 2. TMAX and TMIN ranges for arctic and alpine, boreoarctic, and temperate and boreal species groups, based on data presented in Table I.

Étendue des valeurs de TMAX et TMIN pour les groupes d'espèces arctiques-alpines, boréalesarctiques et tempérées-boréales, selon les données présentées au tableau I.

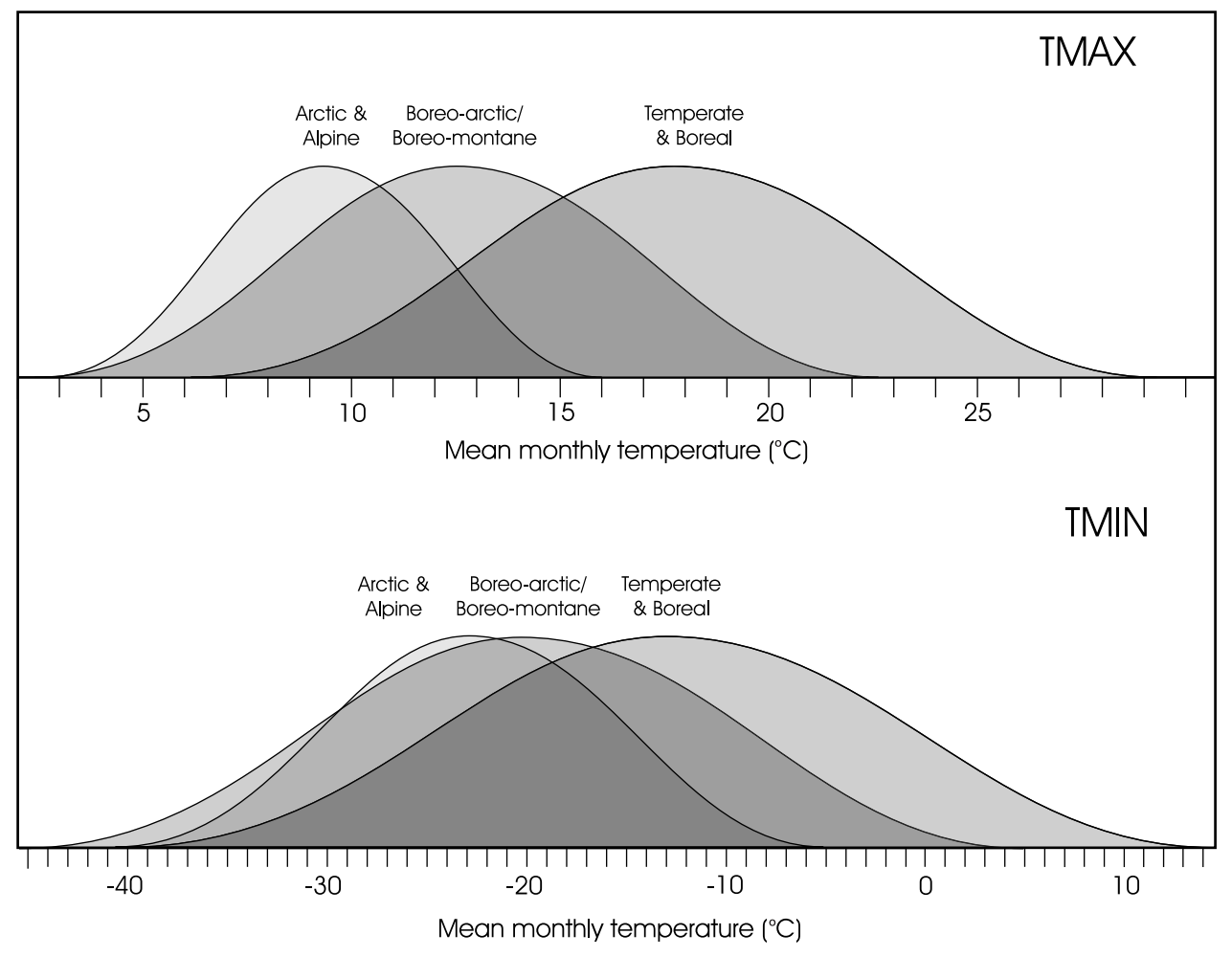

Wisconsinan assemblages from Pennsylvania, and Bembidion dauricum has been found in mid- and late-Wisconsin assemblages in Ontario and lowa, respectively. As has been pointed out by Schwert and Ashworth (1988), arctic and alpine beetles living in the central and eastern United States and southern Canada at the end of the last glaciation were unable to disperse north as climate warmed, because glacial ice blocked their path. Some cold-adapted beetles living in or near the Appalachians or Rocky Mountains, such as Amara alpina, were able to disperse upslope and become established in the alpine tundra zone following deglaciation (Elias, 1991). Other species, like the water scavenger beetle, Helophorus splendidus, lived in the Colorado Rocky Mountains as late as 13000 years ago, but failed to become established in the alpine tundra habitats that formed in the Rockies following deglaciation. Likewise the rove beetle, Holoboreaphilus nordenskioeldi lived in the Rocky Mountains of Montana during the late glacial period, but no Rocky Mountain populations of this species are known to have survived through the Holocene.

The fossil record of such species is very instructive. Were we to base the zoogeographic history of such species as $H$. splendidus or $H$. nordenskioeldi strictly on their modern ranges, these beetles would be classified as "Beringian," because their modern ranges match those of the Beringian fauna. However, the fossil record shows that Pleistocene populations existed far south of Beringia, probably in a narrow band of arctic tundra habitats that bordered the continental ice sheets. These habitats probably persisted for tens of thousands of years, shifting south and north with the wax- ing and waning of ice sheet margins. The Quaternary insect fossil record for North America is relatively poorly known, so it seems likely that other species typically considered "Beringian" may eventually prove to have existed in regions south of continental ice sheets during Pleistocene glaciations.

Nearly half of the species found in the Beringian fossil assemblages have boreo-arctic distributions today. In a sense, these species are the best-adapted to the series of climatic conditions presented in the late Pleistocene of Beringia. They succeeded well during interglacial, glacial, and interstadial periods, because of their ability to live in both arctic- and boreal-style climatic regimes. About one-third of these boreo-arctic beetles are considered Beringian species. Two-thirds of them have been wider-ranging in North America, both in the late Pleistocene and presently.

The climatic classification employed here shows that nearly half of the species diversity in the Beringian fossil assemblages comes from boreal and temperate species. This is an interesting observation, because many of those species only lived in Beringia during the relatively brief interglacial and/or interstadial warm periods. Only one species of this group is considered a Beringian species. Pterostichus gerstlensis is a ground beetle known today only in the boreal regions of Alaska. Of the temperate and boreal species from the late Pleistocene Beringian assemblages, 54 \% (37 species) were found only in deposits dating to the last interglacial period. This was an interval of warmer-than-modern climate, based on fossil beetle evidence (Elias et al., 1999b). Boreal forest expanded throughout much of Eastern Beringia, and with it came boreal and temperate beetles. 
However, as the TMAX data in Table I shows, many of these boreal and temperate species have broad climate envelopes. The minimum TMAX values for these species are not greater than $15.5^{\circ} \mathrm{C}$, a level of summer warmth below that of many interior regions of Alaska and the Yukon today.

Roughly one-third of the boreal and temperate beetle species were found in Beringian fossil assemblages dating to interstadial or glacial intervals. Many of these fossil finds have been ascribed to the Early Wisconsinan interval, based on stratigraphic evidence. In many cases it remains unclear whether these assemblages represent full glacial or interstadial conditions. We have better chronological control over assemblages dating to the last glacial maximum (LGM), because this interval falls within the range of radiocarbon dating. Of the boreal and temperate beetles associated with the Beringian fossil assemblages discussed here, only two species have been identified from LGM deposits: Bembidion morulum and Harpalus amputatus. Bembidion morulum has a modern TMAX of $8.75-15.5^{\circ} \mathrm{C}$. Although I have classified it as a boreal species, it is found today at sites near northern treeline (Churchill, Manitoba) and on coastal tundra in Labrador (Lindroth, 1963). Therefore its modern range is on the cusp between boreal and boreo-arctic. Harpalus amputatus has an unusually broad TMAX range, from 9.5 to $24.5^{\circ} \mathrm{C}$. This corresponds to a geographic range from the northern edge of the boreal forest south to prairie regions of Colorado and New Mexico. This species was found in Middle Wisconsinan interstadial, the LGM, and late glacial deposits in both Alaska and the Yukon.

The late Pleistocene beetle fauna of Beringia was comprised of mixtures of widespread and regional endemic species. It also contained mixtures of species with narrow and broad thermal tolerances. No simple patterns emerge from the fossil data. As with the ancient vegetation of Beringia, the ancient beetle communities were ecological mosaics. Species distribution patterns shifted considerably through the last 140000 years. During the lengthy cold stages, a relatively small number of cold-adapted species dominated most fossil assemblages. The warm episodes, including interstadials and especially the last interglacial period, ushered in large numbers of warm-adapted species. Some of these species were able to persist in Beringia during the glacial intervals, because of their relatively broad thermal tolerances. The changing climatic regimes of the late Pleistocene brought expansion of the ranges of one group of species at the expense of another. At least small populations of many species persisted, even when regional climatic conditions were marginal. Today the arctic and alpine species are the group that are relatively restricted in range, while the boreal species flourish across broad regions of Alaska and the Yukon. When another glaciation occurs, these roles will be reversed. There are still many gaps in our understanding of these processes, and whole regions of the former Beringia await paleoentomological investigation. When making paleoclimatological reconstructions from fossil beetle assemblages, it is tempting to take the fossil data at face value, but we must maintain an ecological and zoogeographic perspective on the data if our interpretations are to be meaningful.

\section{ACKNOWLEDGMENTS}

Funding for the preparation of climate envelopes for Beringian beetle species was provided by a grant from the National Science Foundation, ATM-96126411. I thank Kathy Anderson (INSTAAR) for her help in the preparation of climate envelopes. I also thank Claude Lavoie, Université Laval, who translated the abstract into French.

\section{REFERENCES}

Atkinson, T. C., Briffa, K. R., Coope, G. R., Joachim, M. and Perry, D., 1986. Climatic calibration of coleopteran data, p. 851-858. In B. E. Berglund, ed., Handbook of Holocene Palaeoecology and Palaeohydrology. John Wiley \& Sons, London, $869 \mathrm{p}$.

Ball, G. E., 1966. A revision of the North American species of the subgenus Cryobius Chaudoir (Pterostichus, Carabidae, Coleoptera). Opuscula Entomologica Supplement, 28, $166 \mathrm{p}$.

Bartlein, P. J., Lipsitz, B. and Thompson, R. S., 1994. Modern climate data for paleoenvironmental interpretations, p. 197. In American Quaternary Association, Thirteenth Biennial Meeting, Minneapolis, Minnesota, 275 p.

Coope, G. R., 1977. Fossil Coleopteran assemblages as sensitive indicators of climatic changes during the Devensian (Last) cold stage. Philosophical Transactions of the Royal Society of London, Series B, 280: 313-340.

Danks, H. V., 1981a. The composition distribution and ecology of arctic insects with some speculations on the evolution of arctic communities, p. 21-23. In G. Scudder and J. Reveal, eds., Evolution Today. Proceedings of the Second International Congress of Systematic and Evolutionary Biology, Vancouver, $486 \mathrm{p}$.

1981b. Arctic Arthropods. Entomological Society of Canada, Ottawa, 608 p.

Elias, S. A., 1991. Insects and climate change: Fossil evidence from the Rocky Mountains, BioScience, 41: 552-559.

1992a. Late Wisconsin insects and plant macrofossils associated with the Colorado Creek mammoth, southwestern Alaska: Taphonomic and paleoenvironmental implications, p. 45-47. In 22nd Arctic Workshop, Program and Abstracts, Boulder, Colorado, $197 \mathrm{p}$.

1992b. Late Quaternary beetle faunas of Southwestern Alaska: Evidence of a refugium for mesic and hygrophilous species. Arctic and Alpine Research, 24: 133-144.

1994. Quaternary Insects and Their Environments. Smithsonian Institution Press, Washington D. C., 284 p.

1996. Late Pinedale and Holocene seasonal temperatures reconstructed from fossil beetle assemblages in the Rocky Mountains. Quaternary Research, 46: 311-318.

2001. Mutual Climatic Range reconstructions of seasonal temperatures based on late Pleistocene fossil beetle assemblages in Eastern Beringia. Quaternary Science Reviews, 20: 77-91.

Elias, S. A., Anderson, K. H. and Andrews, J. T., 1996a. Late Wisconsin climate in northeastern USA and southeastern Canada, reconstructed from fossil beetle assemblages. Journal of Quaternary Science, 11: 417-421.

Elias, S. A., Andrews, J. T. and Anderson, K. H., 1999a. Insights on the climatic constraints on the beetle fauna of coastal Alaska, U.S.A., derived from the Mutual Climatic Range method of paleoclimate reconstruction. Arctic, Antarctic, and Alpine Research, 31: 94-98.

Elias, S. A., Hamilton, T. D., Edwards, M. E., Begét, J. E., Krumhardt, A. P. and Lavoie, C., 1999b. Late Pleistocene environments of the western Noatak Basin, northwestern Alaska. Geological Society of America Bulletin, 111: 769-789.

Elias, S. A. and Short, S. K., 1992. Paleoecology of an interglacial peat deposit, Nuyakuk, southwestern Alaska, U.S.A. Géographie physique et Quaternaire, 46: 85-96.

Elias, S. A., Short, S. K. and Birks, H. H., 1997. Late Wisconsin environments of the Bering Land Bridge. Palaeogeography, Palaeoclimatology, Palaeoecology, 136: 293-308. 
Elias, S. A., Short, S. K., Nelson, C. H. and Birks, H. H., 1996b. Life and times of the Bering land bridge. Nature, 382: 60-63.

Elias, S. A., Short, S. K. and Waythomas, C. F., 1996c. Late Quaternary environments, Denali National Park and Preserve, Alaska. Arctic, 49: 292 305.

Guthrie, R. D., 1990. Frozen Fauna of the Mammoth Steppe. The Story of Blue Babe. University of Chicago Press, Chicago, $323 \mathrm{p}$.

Hopkins, D. M., Giterman, R. E. and Matthews, J. V., Jr., 1976. Interstadial mammoth remains and associated pollen and insect fossils, Kotzebue Sound area, northwestern Alaska. Geology, 4: 169-172.

Hughes, O. L., Harrington, C. R., Janssens, J. A., Matthews, J. V., Jr., Morlan, R. E., Rutter, N. W. and Schweger, C. E., 1981. Upper Pleistocene stratigraphy paleoecology and archaeology of northern Yukon interior, eastern Beringia 1. Bonnet Plume Basin. Arctic, 34: 329-365.

Lindroth, C. H., 1963. The ground beetles of Canada and Alaska, part 3. Opuscula Entomologica Supplement, 24: 201-408.

Matthews, J. V., Jr., 1968. A paleoenvironmental analysis of three Late Pleistocene coleopterous assemblages from Fairbanks, Alaska. Quaestiones Entomologicae, 4: 202-224.

1974a. Quaternary environments at Cape Deceit (Seward Peninsula, Alaska): Evolution of a tundra ecosystem. Geological Society of America Bulletin, 85: 1353-1384.

1974b. Wisconsin environment of interior Alaska: Pollen and macrofossil analysis of a 26 meter core from the Isabella Basin (Fairbanks, Alaska). Canadian Journal of Earth Sciences, 11: 828-841.

1975a. Incongruence of macrofossil and pollen evidence: A case from the Late Pleistocene of the northern Yukon coast. Geological Survey of Canada Paper, 75-1B: 139-146.

1975b. Insects and plant macrofossils from two Quaternary exposures in the Old Crow-Porcupine region, Yukon Territory, Canada. Arctic and Alpine Research, 7: 249-259.
1977. Tertiary Coleoptera fossils from the North American arctic. Coleopterists Bulletin, 31: 297-308.

Matthews, J. V., Jr., Schweger, C. E. and Janssens, J. A., 1990a. The Last (Koy-Yukon) interglaciation in the northern Yukon: Evidence from Unit 4 at Ch'ijee's Bluff, Bluefish Basin. Géographie physique et Quaternaire, 44: 341-362.

Matthews, J. V., Jr., Schweger, C. E. and Hughes, O. L., 1990b. Plant and insect fossils from the Mayo Indian Village section (Central Yukon): new data on middle Wisconsinan environments and glaciation. Géographie physique et Quaternaire, 44: 15-26.

Matthews, J. V., Jr. and Telka, A., 1997. Insect fossils from the Yukon, p. 911962. In H. V. Danks and J. A. Downes, eds., Insects of the Yukon. Biological Survey of Canada (Terrestrial Arthropods), Ottawa, $1034 \mathrm{p}$.

Morlan, R. E. and Matthews, J. V., Jr., 1983. Taphonomy and paleoecology of fossil insect assemblages from Old Crow River ( $\mathrm{CRH}-15)$, northern Yukon Territory, Canada. Géographie physique et Quaternaire, 37: 147-157.

Nelson, R. E. and Carter, L. D., 1987. Paleoenvironmental analysis of insects and extralimital Populus from an early Holocene site on the Arctic Slope of Alaska. Arctic and Alpine Research, 19: 230-241.

Preece, S. J., Westgate, J. A., Stemper, B. A. and Péwé, T. L., 1999. Tephrochronology of late Cenozoic loess at Fairbanks, central Alaska. Geological Society of America Bulletin, 111: 71-90.

Schwert, D. P. and Ashworth, A. C., 1988. Late Quaternary history of the northern beetle fauna of North America: a synthesis of fossil distributional evidence. Memoirs of the Entomological Society of Canada, 144: 93-107.

Scudder, G. G. E., 1979. Present patterns in the fauna and flora of Canada, $p$. 87-179. In H. V. Danks, ed., Canada and Its Insect Fauna. The Entomological Society of Canada, Ottawa, $573 \mathrm{p}$.

Waythomas, C. F., Short, S. K. and Elias, S. A., 1989. Deposits of interglacial character, Nenana Valley, Alaska. Current Research in the Pleistocene, 6 : 95-98. 